\title{
THE AUDIT OF FINANCIAL STATEMENTS PREPARED BY THE BENEFICIARIES OF EU GRANT
}

\author{
Dănuţ Rada \\ Drăgan European University of Lugoj \\ radanutdrd@yahoo.com \\ Doina Rada \\ “Eftimie Murgu” University of Reşiţa \\ doinarada@yahoo.com
}

\begin{abstract}
The patrimonial economic entities - public institutions or economic agents, beneficiaries of EU grants, are required to maintain separate accounts situations of the use of these financial resources and also to prepare financial statements in which to be reflected the fees occurred by implementing of projects. The audit of these financial statements is specific and is based on the provisions of international audit standards ISRS 4400 "international standard for related services" and ISAE 3000 "international standard for certification measures”. In some cases, considering the request of the audit beneficiary, can be applied the provisions of ISA 800, International Audit Standard "Special Considerations-Audit of financial statements prepared in accordance with special purpose frameworks".
\end{abstract}

Keywords

patrimonial entities; grants; European Union; audit; financial statements

\section{JEL Classification}

M42

\section{European funds accessing, between needs and responsibilities}

Currently, European funds represent an opportunity for Romania, but at the same time, directly, they also represent an opportunity for businesses and public institutions, that can access, by the projects developed, significant amounts of money for development, modernization, structural changes and cooperation. In order to know and to use in the self-interest the European funds, it is necessary to be aware of the laws, values, operational tools, business opportunities and also economic and geostrategic lines of action. These funds are an expression of freedom and European democracy, based on cooperation and initiative in each country which wants to highlight their cultural values and economic initiatives, supported by the financial resources of the European Economic Community. For a better success it is necessary the knowledge of structural instruments implemented by several regional operational programs (seven in all), plus eight new programs of cooperation with other states.

For this purpose, in Romania, has been appointed the Managing Authority among the ministries, which deals with the program implementation at a territorial level, while, in addition to these, it also operates other intermediary bodies at a central or regional level, depending on the programs adopted.

In collaboration with the European Community, in order to coordinate national programs, it operates the Authority for Coordination of Structural Instruments (ACIS), an institution created in the interior of the Ministry of Finance.

The total amount of Structural and Cohesion Funds allocated to Romania is 19.668 billion Euros, of which 12.661 billion represent funds under the 'Convergence' 
objective, 6.552 billion euro allocated to the Cohesion Fund and allocated 0.455 billion euro allocated for the objective of "European Territorial Cooperation" .

To access these important financial resources made available by the European Union, it was necessary to create a programmatic framework that includes a number of strategic documents for the implementation of Structural and Cohesion Funds in Romania. These are:

- The National Development Plan 2007-2013;

- The National Strategic Reference Framework 2007-2013;

- Operational programs;

- Framework Implementation Documents.

The necessity of these strategic documents was claimed by several factors:

- $\quad$ The need to systematize the multiple requirements of the Romanian economy, to eliminate disparities and gaps to the European Union;

- Creation of a national strategy in order to absorb European funds;

- Ensuring the most efficient use of these funds;

- Ensuring transparency of the destination for European funds;

- Establishment of a charge for those who access and use the European funds, establishing powers and responsibilities to ensure the integrity of European public funds and lack any possibility of fraud.

The later objective also contains the organization of audit activity of expenditures regarding grant funding sources, obtained by applicants, which can be both public and private entities in Romania.

The audit activity, as an external financial control, made by an accountant, a member of a professional union, affiliated to the European accounting bodies comes to provide the assurance for the management authority of European projects that funding sources were used on the purposes determined by the project (legal), they are related to the implementation period and were used with maximum efficiency.

\section{The EU requirements regarding auditing activity of European Projects Audit of the expenditures realized from sources of EU funding}

Like any public funding, those with funding which comes from the European Union funds, should be subjects of financial control to ensure their safety, efficient use and allocation according to established objectives.

In addition to its own control of users of such resources, the sponsor (EU), by managing authorities of Structural and Cohesion programs requires that costs incurred to implement these projects to be checked (audited) by an external expert, independent member of the national professional body.

Requirements are formulated in terms of reference that are transmitted to the auditor and that record the documentation procedures agreed by the contracting authority to be applied in order to ascertain the quality of expenditures, to be incurred on the project (the reality), to be accurate (accuracy) and eligible.

Ethical requirements which need to be applied in carrying out the audit mission are, integrity, objectivity, professional competence, confidentiality and professional conduct. Independence is not a requirement invoked by ISRS 4400, but if it is affected, the situation will be referred in relation.Audit engagement is based on the International Standard of Related Services ISRS 4400 - Commitment to perform agreed-upon procedures regarding financial information, as promulgated by the International Federation of Accountants (IFAC).

The SSRIs are addressed to missions related to financial information and allows the auditor to apply specific procedures agreed by the customer, in order to find some 
facts that can be communicated through a report which in the case of the auditing EU funds, is called "Report of Factual Findings". Since this report only provides feedback on the quality of information in the financial statements of applicants for EU funded projects, it expresses no certification. Procedures applied were determined solely by the contracting authority and serve it to assess whether the costs claimed in the financial report prepared by the beneficiary are eligible under the terms and conditions of the financing contract.

Financial situation over which goes the audit engagement is called Claims for reimbursement of expenses (CRC) or Financial Report. Regardless of the name, this summary includes all costs incurred by the customer in order to achieve the project objectives.

The mission of the auditor is to verify that the expenditure presented by the beneficiary refund application has been made in the interest of the project and that they are correct and payable.

The object of an audit of the type in question is the auditor to perform specific procedures agreed by both sides, but, with the report prepared, the auditor does not express any assurance mission since it is not an audit (review). This report is strictly addressed only to those parties that have agreed to the procedures to be performed.

Since contracting audit work is not done by letter but by contract assignment under the provisions of the Civil Code, the auditor is unable to formulate in accordance with ISRS 4400 - audit requirements.

The basis of the procedures to be applied are the terms of reference for an expenditure verification, emanate from the beneficiary and complying with auditing standards impugned by paragraph 12 .

Audit mission planning will take into account both the provisions of ISRS 4400 and the terms of reference, the role of planning is to streamline the mission, to order it so as expenses to be checked for the most part (materiality threshold being 60\%).

Proper planning will help identify important areas of mission and treat them accordingly to the identifying potential problems with time management and organizational mission; also, adequate designating the tasks of the team members, coordination of work done by other practitioners and experts.

At the beginning of the engagement, critical issues will be analyzed. For instance:

- $\quad$ terms of the mission;

- $\quad$ characteristics of the problem and identified criteria ;

- $\quad$ the mission and possible sources of evidence;

- $\quad$ understanding the entity and risk;

- $\quad$ identify users and their needs;

- $\quad$ analysis of materiality and risk assurance engagements;

- $\quad$ personnel and experience requirements;

- $\quad$ nature and the degree of involvement of the experts.

Documenting of the auditor will aim to obtain sufficient appropriate audit evidence and fair at the same time, able to support the auditor's opinion on the quality of information contained in the application for reimbursement or financial report.

The practitioner (the auditor) will use professional judgment and he will use professional skepticism in the evaluation of the amount of evidence, quality of evidence, credibility of the information. Obtaining a sufficient evidence is a systematic and iterative process that involves:

- $\quad$ obtaining an understanding of the problem, including the internal controls;

- $\quad$ assessment of the risk of distortion of information received;

- developing overall responses and determining the nature, timing and extent of procedures; 
- appropriate risk-carrying procedures identified as for example, inspection, observation, computation, interviewing, testing the effectiveness of controls.

Documents to be checked by the auditors will be in all areas of accounting and financial records of the applicant and in this respect the Terms of Reference transmitted by the Contracting Authority to collect samples refer to:

- Accounting Books under L.82/1991, accounting law and subsequent amendments;

- The budget of the beneficiary into chapters, subchapters, paragraphs and titles;

- Checking balances, both analytical and synthetic;

- Cards account various operations;

- Accounting notes;

- Public procurement files developed in accordance to OUG no.34/2006;

- Contracts and order forms;

- Invoices;

- Statements of work and payment conditions;

- Takeover process;

- Bank statements and orders;

- Contracts of employment concluded between the beneficiary and employees;

- Times - sheets with the actual time worked on the project;

- Payrolls.

Regarding the procedures to be applied both ISRS 4400 and terms of reference, indicate two categories namely general procedures and analytical procedures.

In the stage of appliance of the general procedures the auditor verifies that:

- The request for reimbursement is in accordance with the terms of the financing contract;

- The beneficiary shall keep accounting records for the project using different analytical accounts and accounting system is in accordance with national legislation

- It is possible to evaluate the efficiency and effectiveness of expenditures included in the request for reimbursement;

- Information contained in the request for reimbursement is reconciled with the accounting and beneficiary records.

In the second stage, of analytical procedures, the auditor performs a thorough check of expenditure categories in the request for reimbursement, analyzing if:

- Categories of expenditures from the refund application correspond with the categories of expenses of the project budget;

- Costs incurred correspond to those of the project budget;

- Costs incurred are in accordance with the Grant Agreement;

- The total amount requested by the CRC does not exceed the grant provided for in the grant agreement;

- Budget provisions were modified by reallocation between budget lines of the same chapter and if they have undergone a memorandum to the Contracting Authority.

Sampling for an audit of EU funds is a very important issue given the diversity of activities for a project. After a preliminary risk assessment accompanying each category of expenses, the auditor will select those who are at a high risk. A special note for this type of audit is to check public procurement operations as required by the Contracting Authority issued terms of reference, which should be checked at $100 \%$.

Feature of expenditure on projects with European funding, to be eligible, it is a prerequisite that these expenses be reimbursed by the Contracting Authority. Checking the features (eligibility) costs begins with documentary evidence of 
expenditure performance, or payment for the purchase made. Such bills are reviewed in terms of quality of documents (form and substance), then the corresponding payment orders or other documents of equivalent probative value. The next step in this line (to verify eligibility) will be the highlight mode control in accounting transactions: transaction accounting note, registration card or register warehouse inventory numbers, drawing an acceptance report, preparing a bill for the commissioning etc.

For an expense to be considered eligible for funding under the Agreement, it must meet the following conditions:

- It needs to be designed and provided in the grant agreement;

- It needs to be made and paid by the Beneficiary or his partners before the deadline for submission of the final reimbursement;

- It needs to be recorded in the accounts of beneficiary / partner based on evidence that can be identifiable and verifiable, and be original.

An important issue arising from ISRS 4400 and standard provisions of the Terms of Reference is to verify the accuracy and reality reflected in the request for reimbursement operations or the financial report. It is in this case to determine whether transactions / operations were recorded chronologically in the accounting system and the application for reimbursement and then systematically different analytical accounts of the project. It also verifies that expenditure for a transaction were correctly classified in chapter (section) cost of the project budget and have been used correctly currency exchange rates.

To establish the reality of expenditures, the auditor uses the work procedures as following:

- Verifying the receiving of goods delivered, in terms of indicating the place and date of receipt of registration and accounting management, specifying management and accounting note recording;

- Verification of work performed and services rendered;

- Verification of shipping documents (delivery note, invoice) notes the reception and operation.

Finally the auditor shall express its opinion on reality, legality and accuracy of transactions / operations carried out by project grant of the findings.

The following assurance report shall refer to:

- significant limitations, inherent problems associated with the evaluation;

- identify the party responsible for producing the information contained in the audited financial statements;

- performing the mission according to international ISAE audit standards.

In the report, the practitioner will record, the adequacy of communication as well with those charged with governance, on the relevant aspects of governance interest arising from the assurance engagement.

The practitioner should obtain written statements from the responsible party, regarding authorship accountability for audited financial statements, the request for reimbursement and the expenditure.

In case a written statement might be missing, the practitioner will be able to:

- draw a conclusion with reserves;

- declare the impossibility of expressing a conclusion because of the limited area in which the mission can be applied;

- includes a restriction on the use of the assurance report.

The elements of the report of factual findings are the following:

a) Title: Report of factual findings; 
b) The recipient (usually the client who engaged the auditor - Contracting Authority);

c) Identify specific financial information on which procedures have been agreed;

d) A statement that the procedures performed were those who agreed with the client;

e) A statement that the mission was performed in accordance with International Standard on Related Services;

f) A statement of compliance with auditor independence - although ISRS 4400 - does not require it;

g) Identifying the purpose for which it was performed the procedures agreed;

h) A statement that the procedures performed do not constitute either an audit or examination and therefore do not express any certification;

i) A statement that the report is limited to those parties that have agreed procedures agreed;

j) Date of report;

k) Auditor's address;

l) Signature of the Auditor.

The report containing factual findings above items shall be prepared in duplicate and accompanied by a record receipt for the beneficiary.

As can be seen from the articles, the task of auditing the expenditure for the EU grants is a reasonable assurance engagement, the objective of which is to reduce the mission's risk to a level low enough to allow the auditor to obtain a basis for a positive form of expression of an opinion.

\section{References}

Batude, D. L. (1997), Audit conptabil et financier, Editions Nathan, Paris.

C.A.F.R. (2006), Norme minimale de audit.

C.E.C.C.A.R. (2007), Manualul privind standardele internaţionale de audit, certificare şi etică, Bucharest.

Law No. 82/1991, with subsequent amendments (RO).

Munteanu, V. (coord.) (2003), Control şi audit financiar contabil, Lumina Lex Publishing House, Bucharest.

O.M.F.P. 3055/2009 for the application of accounting regulations in accordance with the Accounting Directives, with amendments and supplements (RO).

O.U.G. 34/2006 on public procurement, with amendments and supplements (RO).

Peres, I., Bunget, O., Peres, C. (2006), Audit financiar contabil, Mirton Publishing House, Timişoara.

Rada, D. (2009), Auditul situaţiilor financiare anuale. Teorie şi practică, Mirton Publishing House, Timişoara. 